\title{
Anterior stafne bone cyst mimicking periapical cyst: a case report
}

\author{
Ji-Young Song* \\ Department of Oral and Maxillofacial Surgery, School of medicine, Jeju National University, Jeju, Republic of Korea
}

Stafne bone cyst ( $\mathrm{SBC}$ ) is a bone defect usually located in the posterior portion of the mandible or mandibular angle below the inferior alveolar nerve. The cases of SBC involving multiple anterior tooth apices and penetrating the mandibular bone are extremely rare. Here we present a case of an anterior-positioned SBC mimicking periapical cyst, which penetrated the mandibular bone, with a review of the differential diagnosis. (J Dent Rehabil Appl Sci 2016;32(3):209-13)

Key words: stafne bond cyst; periapical cyst; submandibualr gland

\section{Introduction}

Stafne bone cyst (SBC) is a bone defect caused by ectopic growth of the salivary gland. It is also known under various other names: Stafne bone cavity, developmental bone defect of the mandible, ectopic salivary gland, mandibular salivary gland inclusion, lingual cortical mandibular bone defect, and submaxillary salivary gland inclusion. ${ }^{1-3} \mathrm{SBC}$ is usually located in the posterior portion of the mandible or mandibular angle, below the inferior alveolar nerve. SBC is very rare (prevalence of $0.1 \%-0.48 \%$ ). It occurs predominantly in males in the 5 th and 7 th decades of life and is usually located in the lingual portion of the mandible. ${ }^{3}$

Periapical cyst is originated from pulpal necrosis which progressed by bacterial infection. ${ }^{4}$ Clinical diagnosis of periapical cyst can be made with satisfaction of such conditions as (1) involved with non-vital tooth, (2) the lesion size is larger than $200 \mathrm{~mm}^{2}$, (3) the shape of the lesion is well-defined circumscribed

\footnotetext{
*Correspondence to: Ji-Young Song

Professor, Department of Oral and Maxillofacial Surgery, Jeju National University Hospital, 102, Jejudaehak-ro, Jeju, Jeju Special Self-Governing Province, 63243, Republic of Korea

Tel: +82-64-717-1845, Fax: +82-64-717-1102, E-mail: 2460song@naver.com Received: July 13, 2016/Last Revision: September 6, 2016/Accepted: September 12,2016
}

radiolucent surrounded by radiopaque line in radiologically, (4) pus like straw-colored fluid discharge via root canal or in the lesion. ${ }^{4}$

The cases of SBC involving multiple anterior tooth apices are rare. ${ }^{5}$ Moreover, to the best of our knowledge, only two cases of SBC penetrating both lingual and buccal plates of the mandible have been reported. ${ }^{6,7}$ Here we present a rare case of an anteriorpositioned SBC penetrating the mandibular bone, with a review of the differential diagnosis.

\section{Case Report}

A 63-year-old female was referred to the Department of Oral and Maxillofacial Surgery for treatment of a radiolucent lesion of the mandible, which was accidentally found on a panoramic radiograph. The patient had no other medical problems and no habitual smoking or drinking.

Clinical examination revealed no specific findings in the extra- and intraoral areas. Dental panoramic

Copyright $\subset 2016$ The Korean Academy of Stomatognathic Function and Occlusion. (c) It is identical to Creative Commons Non-Commercial License. 
examination confirmed a well-defined radiolucent lesion in the left anterior mandible. The root apices of the lateral incisor, canine, and first premolar were involved in the lesion (Fig. 1). An electric pulp test was performed to determine tooth vitality. The lateral incisor and canine were vital. However, we could not test the premolar because it had a metal prosthesis. This was a confounding factor for ruling out a periapical cyst. Computed tomography (CT) revealed an expansion of the buccal cortical bone and penetration of the buccal and lingual bones of the left anterior mandible (Fig. 2). The size of the lesion was $19 \times 12 \times 14 \mathrm{~mm}$ (mesio-distal, bucco-lingual, cranio-caudal). No root resorption was detected (Fig. 3). For further investigation, magnetic resonance

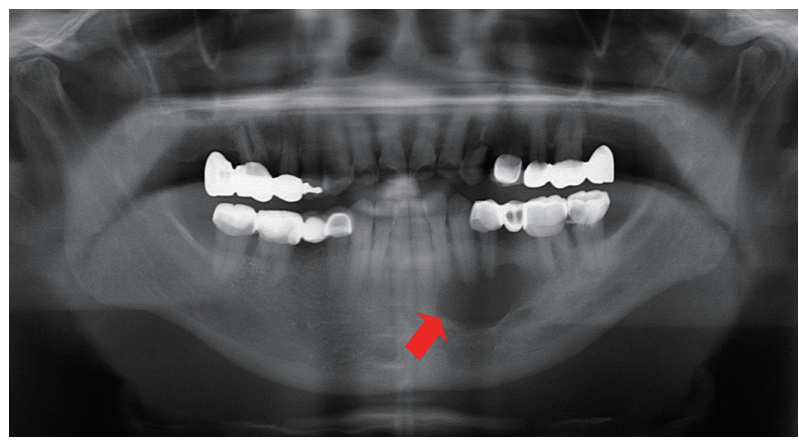

Fig. 1. In the panoramic view, a radiolucent lesion including root apex was detected in the left mandible (arrow).
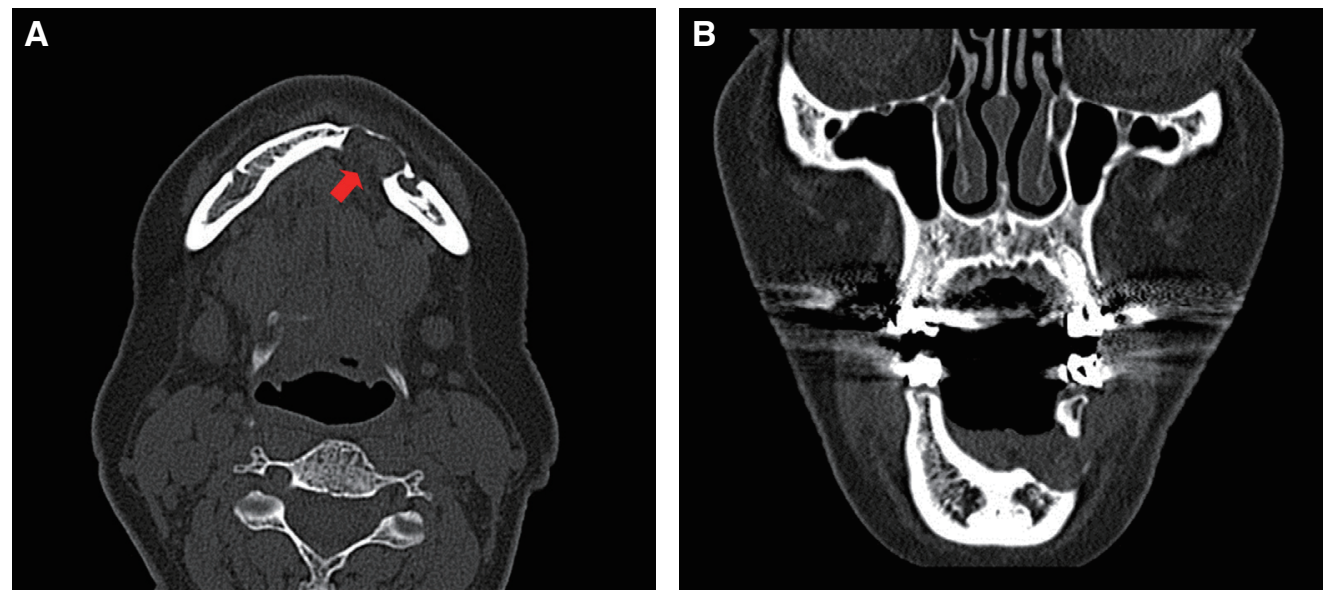

Fig. 2. (A) Computed tomography revealed an expansion of the buccal cortical bone of the left anterior mandible and perforation of the lingual bone (arrow) (horizontal view), (B) Computed tomography revealed penetration of the buccal and lingual bones of the left anterior mandible (coronal view). 

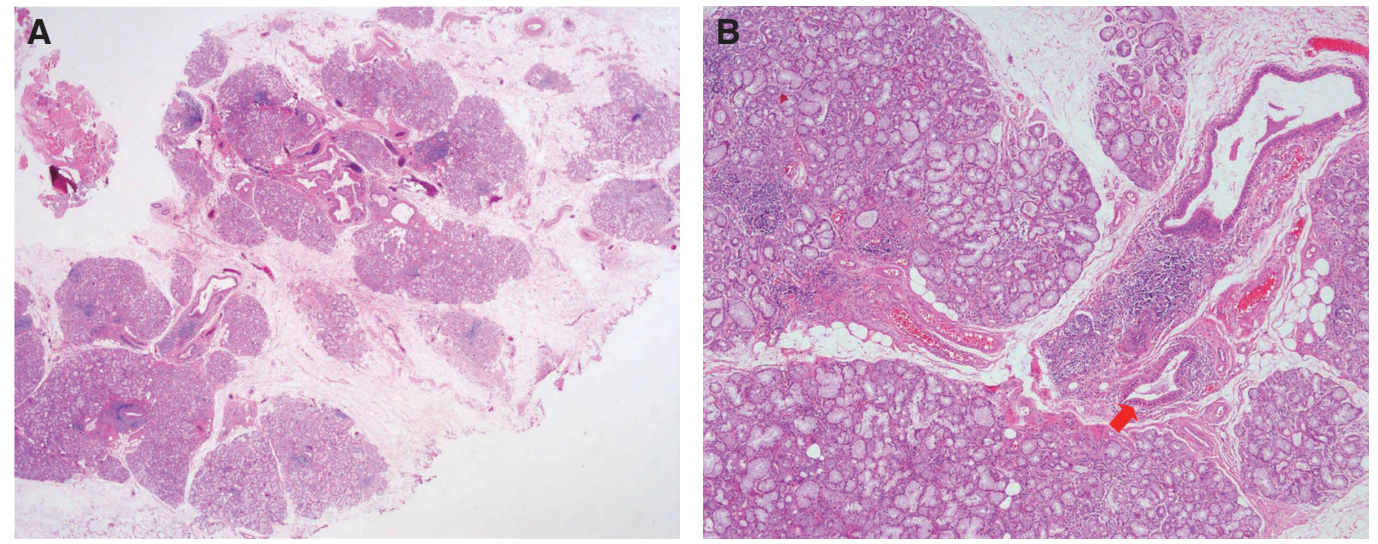

Fig. 4. Histological review showed lobules of seromucinous salivary gland including draining ducts (arrow) (H\&E, (A) $\mathrm{x} 10,(\mathrm{~B}) \mathrm{x} 40)$.

mandibular angle. ${ }^{4,5}$ In 1957, Richard and Ziskind reported similar bone cavities located in the anterior portion of the mandible. ${ }^{1}$ The posterior-located SBC is 7 times more frequent than the anterior one. ${ }^{6}$ The pathophysiology of SBC is still unclear and possible theories have been suggested. ${ }^{3,4}$ One is that SBC originates from entrapped salivary gland during mandible development and ossification. However, SBC commonly occurs in adults rather than at a young age. Therefore, SBC is likely to occur after ossification is complete. Another theory implicates necrosis and resorption of the mandibular bone induced by abnormal pressure of neighboring structures such as vascular components or hypertrophic salivary gland. According to this theory, posterior-positioned SBC originates from the submandibular gland, anteriorpositioned SBC is related to the sublingual gland, and $\mathrm{SBC}$ positioned in the mandibular ramus is related to the parotid gland. ${ }^{1,3,7}$

Usually the cavity is filled with salivary gland tissue, but pleomorphic adenoma, skeletal muscle, lymphoid tissue, fibrous connective tissue, fatty tissue, and blood vessels have been found on rare occasions. ${ }^{1,8}$

Because SBC is asymptomatic, it is found accidentally on a dental panoramic radiograph. In the radiological findings, it has a well-defined sclerotic margin and round or elliptical shape, and is radiolucent. Usually the lesion affects the lingual cortical plate but not the buccal cortical plate, and is a clearly defined lingual defect of the mandibular bone on CT and MRI. Therefore, it should be easily diagnosed by these techniques. ${ }^{2,3,-11}$ In our case, the lesion affected both lingual and buccal cortical plates. This is a rare type of SBC; therefore, the differential diagnosis is more difficult than in typical SBC cases.

The differential diagnosis should be performed for pathologic lesions such as apical or recidual cyst, traumatic bone cyst, dentigerous cyst, odontogenic keratocyst, ameloblastoma, metastasis, eosinophilic granuloma, giant cell tumor, hemangioma, vascular malformation, and other malignant lesions. In the case of a cyst or other benign tumor, some symptoms may be present. ${ }^{1,3,6,12,13}$

As mentioned above, periapical cyst is clinical differential diagnosed with SBC such as (1) existence of one or more non vital tooth involving the lesion, (2) including fluid in the lesion via aspiration. ${ }^{4}$

Radiological examination, such as sialography, CT, and MRI, is useful for diagnosis of typical SBC. The presence of glandular tissue within the cavity is detected via submandibular gland sialography. However, sialography is painful for patients. Moreover, it can be difficult to perform sialography of the anterior portion of $\mathrm{SBC}$, because the ducts of Rivinus have a small diameter. ${ }^{9,13,14}$ MRI is an essential tool for diagnosis of SBC. In particular, T1-weighted images can be useful for the differential diagnosis between salivary gland and other neoplastic lesions. However, MRI also has disadvantages: it is expensive, and in patients with intraoral metal prostheses distor- 
tion artifacts may confound the diagnosis. ${ }^{9,14} \mathrm{CT}$ is also useful for diagnosis of bone defects of lingual origin.' Ariji et al. suggested that CT can be useful for identification of tissue origin within the cavity. ${ }^{15}$ However, CT may be useless for diagnosis of atypical SBC. ${ }^{3,9,10}$

In our case, the patient refused MRI because of the high cost. Because of penetration of the buccal bone by the lesion, it was easily accessible in this case; incisional biopsy was performed with the patient's consent. After the histologic diagnosis confirmed SBC, no further treatment was recommended as conservative therapy with regular radiologic follow-up.

\section{Conclusion}

In conclusion, typical SBC is easily diagnosed with simple radiologic tools such as a panoramic view. However, diagnosis of atypical SBC is very difficult. Even more advanced radiologic tools, such as CT, MRI, and sialography might be useless for diagnosis. Therefore, surgical biopsy may be necessary for the final diagnosis if the lesion is extremely atypical and easily accessible.

\section{References}

1. Kim H, Seok JY, Lee S, An J, Kim NR, Chung DH, Cho HY, Ha SY. Bilateral stafne bone cavity in the anterior mandible with heterotopic salivary gland tissue: a case report. Korean J Pathol 2014;48:2489.

2. Probst FA, Probst M, Maistreli IZ, Otto S, Troeltzsch M. Imaging characteristics of a Stafne bone cavity-panoramic radiography, computed tomography and magnetic resonance imaging. Oral Maxillofac Surg 2014;18:351-3.

3. Herranz-Aparicio J, Figueiredo R, Gay-Escoda C. Stafne's bone cavity: an unusual case with involvement of the buccal and lingual mandibular plates. J Clin Exp Dent 2014;6:e96-9.

4. Fernandes M, de Ataide I. Nonsurgical management of periapical lesions. J Conserv Dent 2010;13: 240-5.

5. Katz J, Chaushu G, Rotstein I. Stafne's bone cavity in the anterior mandible: a possible diagnostic challenge. J Endod 2001;27:304-7.

6. Quesada-Gómez C, Valmaseda-Castellón E, BeriniAytés L, Gay-Escoda C. Stafne bone cavity: a retrospective study of 11 cases. Med Oral Patol Oral Cir Bucal 2006;11:E277-80.

7. Prechtl C, Stockmann P, Neukam FW, Schlegel KA. Enlargement of a Stafne cyst as an indication for surgical treatment - a case report. J Craniomaxillofac Surg 2013;41:270-3.

8. Boffano P, Gallesio C, Daniele D, Roccia F. An unusual trilobate Stafne bone cavity. Surg Radiol Anat 2013;35:351-3.

9. Shimizu M, Osa N, Okamura K, Yoshiura K. CT analysis of the Stafne's bone defects of the mandible. Dentomaxillofac Radiol 2006;35:95-102.

10. Sisman Y, Etöz OA, Mavili E, Sahman H, Tarim Ertas E. Anterior Stafne bone defect mimicking a residual cyst: a case report. Dentomaxillofac Radiol 2010;39:124-6.

11. Kopp S, Ihde S, Bienengraber V. Differential diagnosis of stafne idiopathic bone cyst with Digital Volume Tomography (DVT). J Maxillofac Oral Surg 2010;9:80-1.

12. de Courten A, Küffer R, Samson J, Lombardi T. Anterior lingual mandibular salivary gland defect (Stafne defect) presenting as a residual cyst. Oral Surg Oral Med Oral Pathol Oral Radiol Endod 2002;94:460-4.

13. Sisman Y, Miloglu O, Sekerci AE, Yilmaz AB, Demirtas O, Tokmak TT. Radiographic evaluation on prevalence of Stafne bone defect: a study from two centres in Turkey. Dentomaxillofac Radiol 2012;41:152-8.

14. Branstetter BF, Weissman JL, Kaplan SB. Imaging of a Stafne bone cavity: what MR adds and why a new name is needed. AJNR Am J Neuroradiol 1999;20:587-9.

15. Ariji E, Fujiwara N, Tabata O, Nakayama E, Kanda S, Shiratsuchi Y, Oka M. Stafne's bone cavity. Classification based on outline and content determined by computed tomography. Oral Surg Oral Med Oral Pathol 1993;76:375-80. 


\section{치근단낭과 유사한 stafne 골낭종의 증례 보고}

\section{송지영*}

제주대학교 의학전문대학원 의학과 치과

Stafne 골낭종은 악하선의 발생 시 생긴 하악골의 결손부로 주로 하악골의 후방부나 하악 우각부에 발생한다. 대부분 하 치조 신경관 하방에 발생하며 하악골 전방부에 발생하거나 하악 치아와 연관된 경우는 드물다. 또한 하악골의 천공을 일 으키는 경우는 더욱 드물다. 본 증례는 하악골 전방부에 발생하여 하악골 천공을 일으킨 치근단낭과 유사한 병소가 stafne 골낭종으로 진단된 희귀한 증례로, 이와 유사하게 하악골에 발생 가능한 병소의 감별 진단과 함께 보고하고자 한다.

(구강회복응용과학지 2016;32(3):209-13)

주요어: 악하선; 치근단낭; Stafne 골낭종

*교신저자: 송지영

(63243) 제주특별자치도 제주시 제주대학로 102 제주대학교병원 치과 구강악안면외과

Tel: 064-717-1845 | Fax: 064-717-1102 | E-mail: 2460song@naver.com

접수일: 2016년 7월 13일 | 수정일: 2016년 9월 6일 | 채택일: 2016년 9월 12일 